Vol. 15, no. 1, June 2021, pp. 39-70

10.2478/host-2021-0003

\title{
Global Affinities: The Natural Method and Anomalous Plants in the Nineteenth Century
}

\author{
Lorelai Kury \\ Casa de Oswaldo Cruz, Fiocruz, Brazil \\ lorelai.kury@fiocruz.br
}

Sara Albuquerque

IHC-Nova FCSH, Pólo Universidade de Évora, Portugal

sma@uevora.pt

Abstract: Approaching from an analysis of the work of Robert Brown (1773-1858) and Friedrich Welwitsch (1806-1872) on Rafflesia and Welwitschia, this article explores how the "natural method" became a tool for understanding extra-European flora in the nineteenth century. As botanists worked to detect "hidden affinities" between plants that would enable them to identify the so-called natural families to which even anomalous species belonged, they relied on comparison as their basic methodological procedure, making it essential for them to have access to collections. In their scientific writings, professional botanists tended to steer clear of any emphasis on plant exoticism. While botany engaged in dialogue with various types of approaches, the field essentially normalized the exotic. The article's exploration of the hermetic style of scientific texts and the way botanists incorporated illustrators' work sheds light on the complexity of the spaces where natural history was done, in a context where plants were circulating from around the globe.

Keywords: Rafflesia; Welwitschia; Robert Brown; natural method; exoticism 
This article analyzes how European botany addressed its discoveries of uncommon plants and ensuing challenges in the nineteenth century. Our specific focus is on the cases of Rafflesia and Welwitschia and the circumstances under which these plants were described and classified. On the one hand, specialized botany worked to bring what was anomalous and foreign into the realm of normalcy through its theories and painstaking analytical techniques; on the other, the bizarre nature of these plants fostered the circulation of texts and images about the "exotic" topics that were then drawing interest among readers in major European cities, readers who were also avid consumers of travel and adventure accounts. We are concerned especially with the work of two figures: Robert Brown (1773-1858), a preeminent Scottish botanist of his generation, and Friedrich Martin Joseph Welwitsch (1806-1872), an Austrian explorer and botanist. We also look at how non-specialized narratives about curiosities and exotic products engaged in dialogue with specialized texts in botany.

\section{Philosophical botany}

Brown was born in Montrose, Scotland, and studied medicine at the University of Edinburgh, although he never received a degree. He worked as a military surgeon until 1801, when he signed on as a naturalist with Captain Matthew Flinders's expedition to the Pacific, where he spent four years exploring the region. Based on the collections he gathered during these travels, Brown was able to publish important works about the flora of New Holland (now Australia). While serving as a librarian for Sir Joseph Banks, beginning in 1810, he also took the opportunity to publish on material received from correspondents around the world. After returning from the Pacific, he served as clerk, librarian, and housekeeper for the Linnean Society of London from 1805 to $1822 .{ }^{1}$ When Banks died in 1820, Brown transferred to the British Museum, where he worked the remainder of his life. ${ }^{2}$

Brown was admitted to Banks's circles and maintained correspondence with collectors and naturalists from around the world, particularly naturalists in Scotland, England, and other parts of Europe, especially French- and German-speaking regions. Brown had a hand in introducing Antoine-Laurent de Jussieu's natural method to Britain. During his travels to the Pacific, he tried to apply the natural method in the arrangement of his collected plants. Because this proved time-consuming and he had many doubts about the affinity of plants, he ended up relying on Linnaeus's traditional method, which was more practical during fieldwork. ${ }^{3}$

\footnotetext{
${ }^{1}$ See The Linnean Society, “Robert Brown (1773-1858)," https://www.linnean.org/the-society/historyof-science/robert-brown, accessed June 30, 2020.

2 David J. Mabberley, Jupiter Botanicus: Robert Brown of the British Museum (Braunschweig: Cramer, 1985).

${ }^{3}$ Letter from Robert Brown to Joseph Banks, Sydney, August 6, 1803, in Nature's Investigator. The Diary of Robert Brown in Australia, 1801-1805, comp. T.G. Vallence, D.T. Moore and E. W. Groves (Canberra:
} 
In the early nineteenth century, most European and American botanists used the Linnaean system to describe and classify plants. For Linnaeus, the key to classification was the number of pistils and fertile stamens, even if this meant clearly discrete groups were combined in some cases. Linnaeus himself realized that his system produced somewhat artificial results. As botanists "discovered" huge numbers of plants in the eighteenth century, the Linnaean system grew increasingly awkward for establishing kinships between plant groups. The method introduced by Jussieu relied on hierarchy to establish the order of importance among features, which Georges Cuvier dubbed the principle of "subordination of characters." ${ }^{3}$ The families organized by Jussieu seemed much more natural than Linnaean groups. In a text published in 1811, Brown drew an explicit relation between the significant increase in the number of known plants and the need for botany to align its methods with this new reality:

The vast additions to the number of species which botany is constantly receiving, while they make a natural arrangement absolutely necessary to the general botanist, render it at the same time proportionally difficult. For though there are still many tribes of plants easily distinguishable even by a superficial observer, yet there are others, that hitherto have been thought abundantly distinct, which can no longer be circumscribed by means of characters taken from their organs of reproduction. ${ }^{5}$

Historians of science have argued that while it was Jussieu who launched the natural method, it was the works of both Augustin Pyramus de Candolle, Swiss naturalist, and Brown that furthered its development and effective use. ${ }^{6}$ Candolle ${ }^{7}$ combined Jussieu's method with specific theories on plant development, consonant with the ideas put forward by Johann Wolfgang von Goethe in Versuch die Metamorphose der Pflanzen zu erklären (Metamorphosis of Plants), first published in 1790. Candolle's Théorie élémentaire de la botanique (Elementary Theory of Botany) ${ }^{8}$ was released in 1813, followed by Prodromus systematis naturalis regni vegetabilis, ${ }^{9}$ the first volume of which came out in 1824.

Australian Biological Resources Study, 2001), 419.

${ }^{4}$ Peter F. Stevens, The Development of Biological Systematics: Antoine-Laurent de Jussieu, Nature, and Natural System (New York: Columbia University Press, 1994), 66.

5 Robert Brown, "On the Asclepiadeae, a Natural Order of Plants separated from the Apocineae of Jussieu," Memoirs of the Wernerian Natural History Society 1 (1811): 12-78, on 12.

${ }^{6}$ Sara T. Scharf, "Identification Keys, the 'Natural Method', and the Development of Plant Identification Manuals," Journal of the History of Biology 42, no. 1 (2009): 73-117; Frans A. Stafleu, Linnaeus and Linnaeans. The spreading of their ideas in systematic botany, 1735-1789 (Utrecht: A. Oosthoek's Uitgeversmaatschappij, 1971); Stevens, The Development of Biological Systematics, 66.

7 Patrick Bungener, Pierre Matille and Martin Callmander, Augustin-Pyramus de Candolle, une passion, un jardin (Lausanne/Geneva: Favre/CJBG, 2017).

${ }^{8}$ Augustin Pyramus de Candolle, Théorie élémentaire de la botanique; ou, Exposition des principes de la classification naturelle et de l'art de décrire et d'étudier les végétaux (Paris: Déterville, 1813).

${ }^{9}$ Augustin Pyramus de Candolle, Prodromus systematis naturalis regni vegetabilis sive enumeratio contracta ordinum generum specierumque plantarum huc usque cognitarium, juxta methodi naturalis, normas digesta 1st part (Paris: Treuttel et Würtz, 1824). 
Concerning plant development, Goethe held that all plant organs are the result of the development of the leaf, ${ }^{10}$ which he considered a kind of archetypal form that undergoes "metamorphoses," thus generating all parts of the plant. He demonstrated how cotyledons, stems, petals, etc. are in fact modified leaves. He also argued that plants follow vertical, symmetrical, and spiral tendencies in their germination and growth. By expanding and contracting in a continuous flux, plants reveal the "eternal flexibility of life." ${ }^{11}$ Candolle used the notion of "symmetry" to explain plant development. He believed plants follow a plan, an ideal form, which is transformed during the process of plant development. He used terms like "deviations" or "abnormalities," which did not make sense to Goethe. For Candolle, the diversity of organs within a single plant and the plurality of distinct plants in the world could be understood in terms of change, fusion, and abortion. What Goethe and Candolle had in common, therefore, was the belief that botany could detect the symmetries hidden by the visible irregularities of plant form.

In the early decades of the nineteenth century, followers of philosophical botany saw their field as laying a kind of foundation for the natural method. The author who wrote the preface to the Swiss edition of Goethe's Metamorphosis of Plants explained it this way:

It would be absolutely impossible to understand the natural relationships of the plants being compared if there were no means of evaluating the various disguises which the organs assume before our very eyes; and on the other hand, the true nature of the organs themselves can be disclosed to us only if we compare analogous parts of a great number of varied plant genera. ${ }^{12}$

Philosophical botany makes it possible to identify affinities and kinships between plants because it accompanies the subtlest changes that occur during plant growth, allowing anomalous forms to become familiar. ${ }^{13}$ Even a plant never seen by Europeans could be assigned to a natural family or taxon. If a botanist knew exactly which family the species should be assigned to, he could make predictions and establish patterns. Candolle pointed to one of the method's most promising features in his 1804 book Essai sur les propriétés médicales des plantes (Essay on the medical properties of plants), in which he suggested that knowledge of natural kinships might

${ }^{10}$ Stevens, Development of Biological Systematics; Francesco Moiso, Goethe: la natura e le sue forme (Milan: Mimesis, 2002); Michel Guédès, "La théorie de la métamorphose en morphologie végétale: Des origines à Goethe et Batsch," Revue d'histoire des sciences 22, no. 4 (1969): 323-63; Theresa M. Kelley, Clandestine Marriage: Botany and Romantic Culture (Baltimore: The Johns Hopkins University Press, 2012).

${ }^{11}$ Johann Wolfgang von Goethe, Goethe's Botanical Writings (Woodbridge, CT: Ox Bow Press, 1989), 211.

12 Goethe, Goethe's Botanical Writings, 209. See also Johann Wolfgang von Goethe, Essai sur la Métamorphose des plantes (Geneva: J. Barbezat et Cie., 1829), VI.

${ }^{13}$ In this paper, we use the term "anomalous" to designate plant species that diverge from the taxonomic norm. The two species of concern here, Rafflesia and Welwitschia, are anomalous in the sense that the former has no leaves and only a very small stem, while the latter combines characteristics from quite different groups of plants, for example, gymnosperms and angiosperms. 
help identify the medicinal properties of plants. He offered countless examples: all plants from the Violaceae family seemed to display a greater or lesser degree of emetic virtues; the narcotic properties of the opium poppy (Papaver somniferum) could also be found in other Papaveraceae, like the common poppy (Papaver rhoeas), and probably also in the Mexican poppy (Argemone mexicana) and in bloodroot (Sanguinaria canadensis); and, lastly, Chenopodiaceae were emollients, fit for human consumption. ${ }^{14}$

Candolle argued that although one might think these analogies were unfounded, that was because the properties were restricted to specific parts of the plants. The laws of analogy thus suggested that virtues were shared not only by the same families but also by the same organs. Within a given family, one kind of part—roots, stems, leaves, seeds—had its own notable properties. Candolle believed that if more in-depth knowledge were available on the details of natural families and their properties, the laws of analogy would become more apparent. In theory, one of the implications of his line of thought was that universal procedures could be established, thereby freeing Europeans from their dependence on native knowledge in newly colonized lands; in other words, rather than having to trust local knowledge, Europeans could be guided by the laws of analogy. The European doctors and naturalists who settled in what Candolle called the "new centers of civilization"-like the "two Americas, Bengal and New Holland"—could quickly and safely become "useful to Humanity," guided by the affinities of plants rather than testing them at random. Candolle gave another example of the usefulness of the laws of analogy: European travelers could compare plants they had never had contact with to plants they knew quite well. He cited the example of Georg Forster, who, during a voyage to the South Seas, used a native Cruciferae (currently known as Brassicaceae) as a remedy for scurvy.

As we can see, in the first half of the nineteenth century, botanists were busy tackling crucial problems in plant classification, geography, morphology, and physiology, and this knowledge depended on their ability to make comparisons. Jussieu, Candolle, and Brown were at an advantage here because they had large herbaria at their disposal.

\section{The scientific authority of Robert Brown}

Following his return from the Pacific, Brown complemented his own collection by exchanging dried plants and seeds with other naturalists; Brown also inherited Banks's collections after his death. The 1810 publication of Prodromus florae Novae Hollandiae et Insulae van-Diemen (Prodr. Fl.) launched Brown internationally. By the end of 1810, he had distributed this work to the most important naturalists in Britain and continental Europe. In 1811, he began receiving

${ }^{14}$ Augustin P. Candolle, Essai sur les propriétés médicales des plantes (Paris: Crochard, 1816). The previous citations refer to pages 96,116, and 242; the subsequent ones, to pages 8,9 , and 10 . 
letters from renowned naturalists on the mainland, especially in France. ${ }^{15}$ Jussieu wrote to him in June 1811, telling him that no botanical text had interested him more than Prodr. Fl. Jussieu also mentioned that Brown had improved on the method he himself had followed in Genera plantarum (1789). ${ }^{16}$

That same year, Brown also received a laudatory letter from José Correia da Serra, a Portuguese diplomat and man of science who had introduced him to Banks and, most likely, to Jussieu's system as well. Correia was an interesting figure and a preeminent Freemason. ${ }^{17} \mathrm{He}$ was one of the first to apply the natural method. In 1800, he used it in a text published in Transactions of the Linnean Society. ${ }^{18}$ In 1805 , he published a memoir on the Citrus genus and its family, in which he developed the concept of symmetry, a notion that would prove essential to the work of his close friend Candolle. In 1811, writing a review of Brown's Prodr. Fl. for the journal of the Société Philomatique de Paris (Philomatic Society of Paris), Correia proclaimed the book to be the most important contribution to the knowledge of natural families since Jussieu's Genera Plantarum. ${ }^{19}$ According to the then-young naturalist Alfred Moquin-Tandon, Correia had shown botanists that plant analysis should not be done from the top down or from the outside in (de haut en bas, ou de dehors en dedans), but precisely the other way around, since plant parts develop successively in nature, starting from a common faisceau (sheaf). ${ }^{20}$

Brown's scientific authority grew steadily following publication of Prodr. Fl. In 1814, he published "General remarks, geographical and systematical, on the Botany of Terra Australis," which appeared as an appendix to A voyage to Terra Australis: undertaken for the purpose of completing the discovery of that vast country, by Matthew Flinders. ${ }^{21}$ After reading this text, Louis-Claude Richard, a major French botanist, wrote Brown to tell him that he had shown "great wisdom in the discovery of affinities that were so hard to apprehend." He also said

15 On scientific relations between France and England during the Napoleonic wars, see Iain P. Watts, "Philosophical Intelligence: Letters, Print, and Experiment during Napoleon's Continental Blockade," Isis 106, no. 4 (2015): 749-70.

16 Mabberley, Jupiter Botanicus, 171.

${ }_{17}$ Ana Simóes, Maria Paula Diogo and Ana Carneiro, ed., Cidadão do Mundo. Uma biografia científica do Abade Correia da Serra (Porto: Porto Editora, 2006); Pedro M. P. Raposo, Ana Simões, Manolis Patiniotis and José R. Bertomeu-Sánchez, "Moving Localities and Creative Circulation: Travels as Knowledge Production in 18th-Century Europe," Centaurus 56, no. 3 (2014): 167-88.

${ }^{18}$ José Francisco Correia da Serra, "On two genera of plants belonging to the natural family of Aurantia," Transactions of the Linnean Society 5 (1800): 218-26; Mabberley, Jupiter Botanicus, 144.

19 José Francisco Correia da Serra, "Ouvrage nouveau. Prodromus Florae Novae Hollandae et insulae Van Diemen, etc. a Roberto Brown. Vol. prim. Londini, 1810,” Nouveau Bulletin des Sciences (1811): 235-36.

20 Alfred Moquin-Tandon, Essai sur les dédoublements ou multiplications d'organes dans les végétaux (Montpellier: Jean Martel le Jeune, 1826), 6.

${ }^{21}$ Robert Brown, "General remarks, geographical and systematical, on the Botany of Terra Australis," in A voyage to Terra australis, ed. Matthew Flinders (London: G. and W. Nicol, 1814). 
Brown had a philosophical eye, and so he enjoyed reading his analyses, even when Brown wrote about plants the Frenchman himself did not work with. ${ }^{22}$

The twentieth-century botanist Frans Stafleu named Brown as the main example of what he called "British romantic empiricism," ${ }^{23}$ owing to his proximity to French authors. Stafleu did not develop this idea further, but in a discussion of natural classification in the first half of the nineteenth century, Peter Francis Stevens, botanist and historian of biology, placed Brown on the opposite end from the "idealistic" Germans, because, after Stevens himself, Brown and others "were averse to the use of virtually all abstractions and metaphors." ${ }^{24}$

Even though Brown avoided metaphorical vocabulary, philosophical botanists nevertheless considered him one of them. Goethe himself, in an article with comments on naturalists who embraced his ideas, described Brown's style with these words:

In this series we should give honorable mention to a name of importance, that of Robert Brown. It is characteristic of this great man rarely to mention the fundamental truths of his science, and yet each work of his shows how intimately acquainted he is with those truths. Hence the complaints about his obscurity of style. On the subject of metamorphosis also he has never fully declared himself. Only once, in a casual note in his essay on Rafflesia, does he state explicitly that he considers all flower parts as modified leaves, attempting then to explain the normal formation of anthers from this point of view. These casually uttered words of the botanist recognized as the greatest of our time have fallen on fertile soil and have had profound influence, especially in France. ${ }^{25}$

\section{On Rafflesia and exoticism}

The memoir "An Account of a new Genus of Plants, named Rafflesia" (1822) is a good example of Brown's detective-like method. He was peerless in his ability to discover the most hidden affinities among plants and in cross-referencing this information to form new taxa. He gained incredible skill in the use of magnifiers and could visualize tiny features better than most botanists. Today, his name is often cited in relation to his descriptions of Brownian motion in 1827, that is, the random motion of particles (in this case, pollen) in a fluid. However, many years before making this observation, he was using microscopes and other magnifying glasses to detect the hidden features of plants.

22 Letter from Louis-Claude Richard to Robert Brown, Paris, November 1814, Robert Brown Correspondence, vol. II, Natural History Museum, London.

23 Stafleu, Linnaeus and Linnaeans, 218.

${ }^{24}$ Stevens, The Development of Biological Systematics, 75.

${ }^{25}$ Goethe, Goethe's Botanical Writings, 204-05. 
The plant that Brown christened Rafflesia arnoldii ${ }^{26}$ is endemic to Sumatra. In 1818, Banks received fragments of this plant along with a drawing of it, and these ended up in Brown's hands. The story of this rare flower's complicated journey from Indonesia to London wrapped it in an aura of mystery and also fueled controversies over what the species should be called. ${ }^{27}$ Rafflesia was enormous; it had neither leaves nor branches and emitted a putrid odor, as the collector described it. ${ }^{28}$ Apparently the flower lacked the parts that comprise the structure of common plants, such as stamens and anthers. Brown examined how its characters suffered "deviations," such as reduction, increase, alteration, or disguise. The article reached a wider audience, beyond the usual public with an interest in scientific papers, and the strange flower aroused the curiosity of learned people across Europe. Brown even sent a copy of it to the Empress of Russia. The botanist's style in the first part of the text was less dry and obscure than usual, because he quoted from a letter by Joseph Arnold, the doctor who had found the Rafflesia flower in Sumatra. Striking and pictorial, Arnold's account differs greatly from the rest of the article. The illustrations by Franz Bauer made Brown's memoir even more inviting to read, especially the first one, which was colored and included a scale that indicated the flower's extraordinary size. The engraver James Basire managed to retain the clarity of the original drawings (Figure 1).

\footnotetext{
${ }^{26}$ Robert Brown, "An Account of a new Genus of Plants, named Rafflesia," Transactions of the Linnean Society of London XIII (1822): 201-34. Brown wrote Rafflesia arnoldi.

27 See Timothy P. Barnard, "The Rafflesia in the Natural and Imperial Imagination of the East India Company" in The East India Company and the Natural World, ed. Vinita Damodaran, Anna Winterbottom and Alan Lester (London: Palgrave Macmillan, 2015), 147, 166. See also David J. Mabberley, "Robert Brown on Rafflesia," Blumea: Journal of Plant Taxonomy and Plant Geography 44, no. 2 (1999): 343-50. ${ }^{28}$ Letter from Joseph Arnold to Sir Stamford Raffles quoted in Brown, "An Account of a new Genus of Plants," on 203.
} 


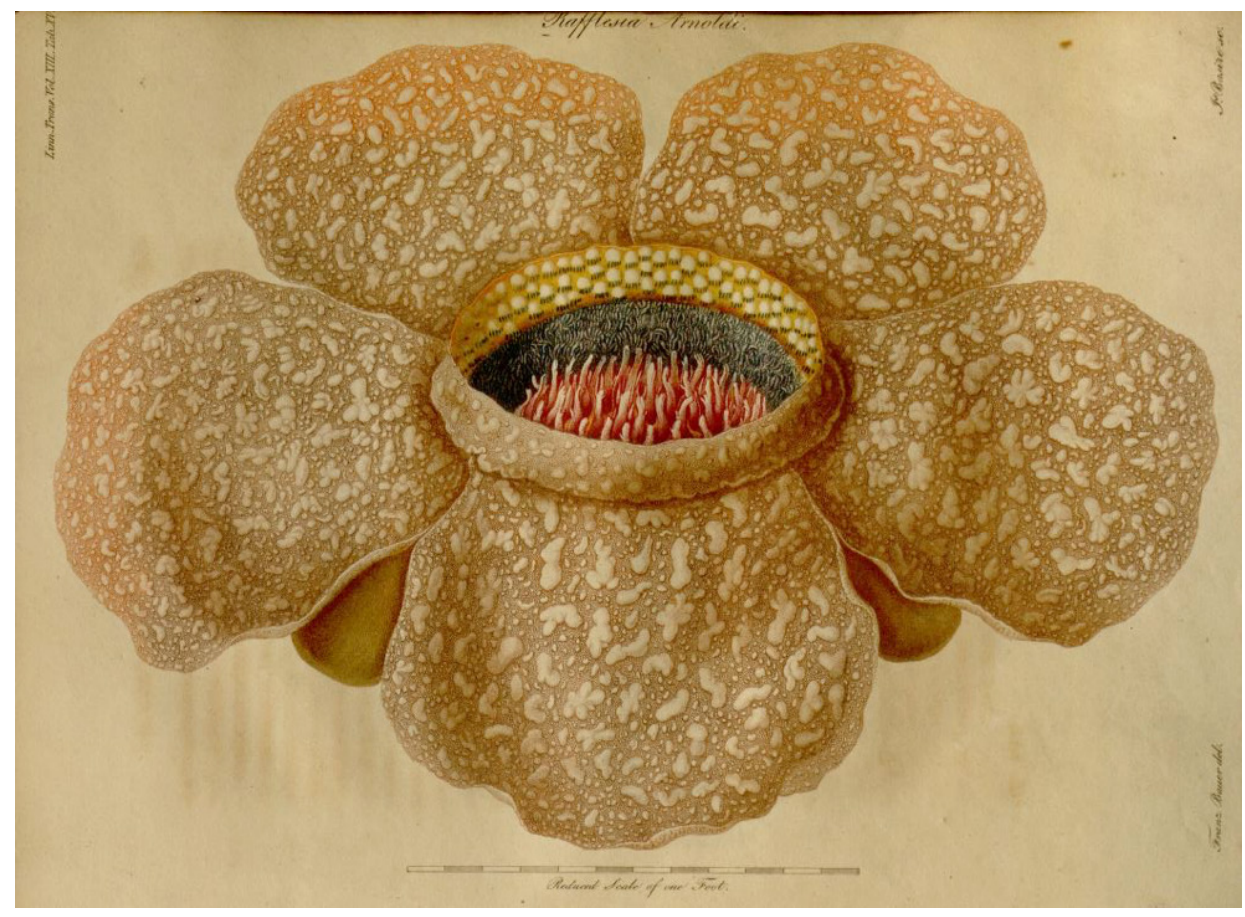

Figure 1. Rafflesia arnoldi, by Franz Bauer, plate XV, in Brown, "An Account of a new Genus of Plants." Image from the Biodiversity Heritage Library, contributed by Missouri Botanical Garden, Peter H. Raven Library, www.biodiversitylibrary.org

Many felt that Franz and his brother Ferdinand, both from Austria, were the period's most talented natural history artists. ${ }^{29}$ In the late eighteenth century, Franz, through the assistance of Banks, was appointed resident artist at Kew gardens and named painter to King George III. His expertise and knowledge earned him recognition not only as an artist but also as a botanist,$^{30}$ then a position of greater status. Many of his works were the product of meticulous microscopic observations, and his images of Rafflesia evince his observational and artistic skills. Images 4 and 8 within plate XXI, for example, represent "an anthera, magnified three diameters,"31 along with transverse and vertical sections (Figure 2). Brown noted that Bauer had illustrated the plant structure "admirably." His admiration lay in the fact that Bauer had identified the plant components and depicted them true to the botanist's own interpretation. ${ }^{32}$

${ }^{29}$ Paul Martyn Cooper, Images of Nature. The Bauer Brothers (London: Natural History Museum, 2015); Hans-Walter Lack, The Bauers: Joseph, Franz \& Ferdinand. Masters of Botanical Illustration (Munich: Prestel, 2015).

${ }^{30}$ Lorraine Daston and Peter Galison, Objectivity (New York: Zone Books, 2007), 97.

${ }^{31}$ Brown, "An Account of a new Genus of Plants," 234.

32 In terms of "epistemic virtues," both Brown and Franz Bauer pursued "truth" and not "objectivity," to use the terms proposed by Lorraine Daston and Peter Galison; in other words, in their analyses, specific specimens were described as "types." See Daston and Galison, Objectivity. 
Hans-Walter Lack writes that Brown and Bauer worked as collaborators, playing different roles but without any hierarchical distinction. Unlike Brown, neither of the Bauer brothers had the advantage of knowing Latin, nor did they publish their own textual descriptions. ${ }^{33}$

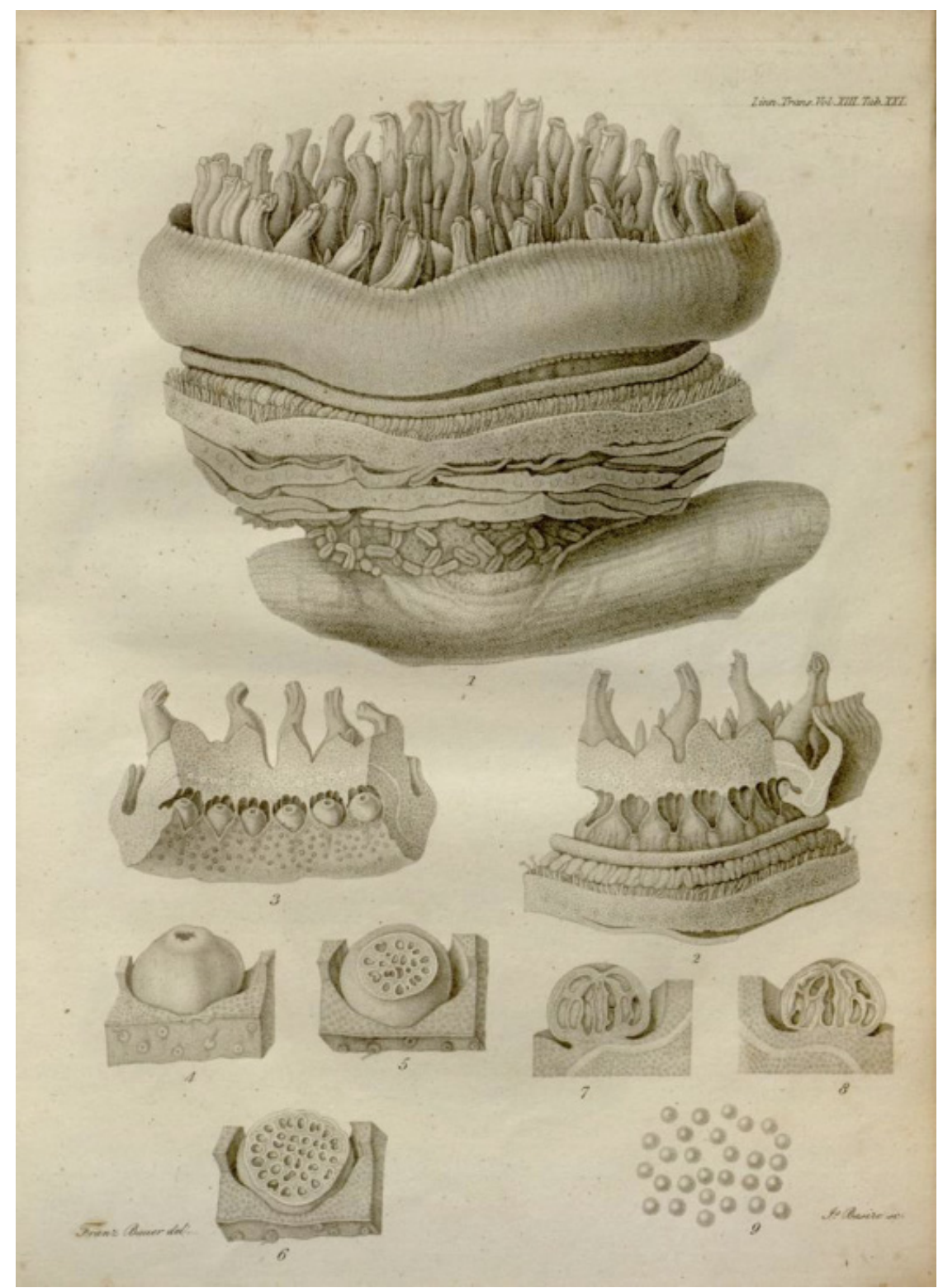

Figure 2. Rafflesia arnoldi, by Franz Bauer, plate XXI, in Brown, "An Account of a new Genus of Plants." Image from the Biodiversity Heritage Library, contributed by Missouri Botanical Garden, Peter H. Raven Library, www.biodiversitylibrary.org

${ }^{33}$ Lack, The Bauers, 364. 
In general, Brown made little effort to please non-specialized readers. He never published anything close to a travel narrative telling of exotic and distant lands; his travel diaries, written in nearly illegible handwriting, were transcribed, and released in full only in 2001, by an Australian publisher. ${ }^{34}$ The type of information presented by Brown, such as circumstances of collection and localization, can be very helpful to the field of botany when cross-referenced with his collections, while it also provides a wealth of information for historians. However, the diaries reflect Brown's style: not very imaginative, an abundance of technical information, and rare descriptions of any picturesque landscapes or adventurous events. Even his accounts of meetings with Pacific Islanders are far from enthralling.

The text "General remarks, geographical and systematical, on the Botany of Terra Australis" makes it clear that Brown was writing for a restricted audience: "In the following pages, I have endeavored to collect such general, and at the same time strictly botanical, observations on the vegetation of Terra Australis, as our extremely limited knowledge of this vast country appears already to afford." ${ }^{35}$

Unlike many other travelers and botanists before and after him, Brown never ventured into the market of personal travel accounts. ${ }^{36}$ Instead, he limited himself to publishing botanical analyses for a relatively restricted audience of specialists. According to Mabberley, Brown's Prodr. Fl. sold very poorly. ${ }^{37}$ It was an extremely technical book and failed to include the images that Ferdinand Bauer had produced during the expedition. While natural history was stirring some interest then, publishers sometimes only accepted works of botany, zoology, and mineralogy because they came accompanied by beautiful images, luring many more readers than those interested in dry technical explanations. ${ }^{38}$ Brown is a representative of both the emerging professionalization of science itself and an increasingly clear tendency to aim scientific texts at a specialized public with ties to public or private institutions. ${ }^{39}$ Botanical articles often

${ }^{34}$ Robert Brown, Nature's Investigator. The Diary of Robert Brown in Australia, 1801-1805, comp. T.G. Vallence, D.T. Moore and E.W. Groves (Canberra: Australian Biological Resources Study, 2001).

35 Robert Brown, "General remarks," 532.

${ }^{36}$ On travel books and exoticism, see Nancy Leys Stepan, Picturing Tropical Nature (London: Reaktion Books, 2001), especially regarding Alfred Russel Wallace's travel narratives.

${ }^{37}$ Mabberley, Jupiter Botanicus, 169.

${ }^{38}$ On the complex role of images in the identity of botanists, see Anne Secord, "Botany on a Plate: Pleasure and the Power of Pictures in Promoting Early Nineteenth-Century Scientific Knowledge," Isis 93, no. 1 (2002): 28-57.

39 On the construction of scientific authority and on professionalization and specialization in science in the first half of the nineteenth century in Europe, see, among others, Matthew Adkins, "The Renaissance of Peiresc: Aubin-Louis Millin and the Post-Revolutionary Republic of Letters," Isis 99, no. 4 (2008): 675-700; Jean-Luc Chappey, "Enjeux sociaux et politiques de la 'vulgarisation scientifique' en révolution (1780-1810)," Annales Historiques de la Révolution Française 338 (2004): 11-51; Christian Licoppe, La formation de la pratique scientifique. Le discours de l'expérience en France et en Angleterre (1630-1820) (Paris: La Découverte, 1996); Simon Schaffer, "Late Enlightenment Crises of Facts: Mesmerism and 
targeted a more restricted reading audience, although botany generally drew broader interest. ${ }^{40}$ Various individual practitioners, from leisured amateurs to artisan naturalists, ${ }^{41}$ accompanied developments in botany through their correspondence and social networks. According to David E. Allen, the 1830 s saw a growing propensity to direct specialized scientific writing toward learned journals. ${ }^{42}$ At the same time, the nineteenth century witnessed a rising trend to aim scientific culture at a broader public. ${ }^{43}$ In any case, by the closing decades of that century, the separation between professionals and amateurs was much more distinct. ${ }^{44}$

Brown's writing style was considered particularly hermetic. The botanist Karl von Martius, his friend and admirer, recognized this characteristic with these words: "Where he was not bound, as in descriptive works, to a rigid systematic style, he ran into a discursive manner, which renders his works difficult of study by the uninitiated, but exerts a peculiar charm over the instructed mind." ${ }^{45}$ Furthermore, Brown was often erratic in his correspondence, which ran counter to the customs of scientific sociability typical of the Enlightenment and the early nineteenth century.

An author's participation in the circuit of specialized publications began to depend on several things: skill in using such instruments as lenses and microscopes, access to large collections, and familiarity with the pertinent literature. Brown constructed his scientific authority by addressing complex, uncertain cases as well as through his relations with Banks, the Linnean Society, and the British Museum. He held a central place in networks of information and the circulation of natural products originating outside of Europe. His writing, however, was devoid of exoticism, except when he cited excerpts from eye-witness accounts or letters; never did it appear in his own words. Even the images of Rafflesia that he uses are hardly striking; other

Meteorites," Configurations 26, no. 2 (2018): 119-48.

40 Jonathan Topham, "The Scientific, the Literary and the Popular: commerce and the reimagining of the scientific journal in Britain, 1813-1825," Notes and Records 70, no. 4 (2016): 305-24.

${ }^{41}$ Anne Secord, "Science in the Pub: artisan botanists in early nineteenth-century Lancashire," History of Science 32 (1994): 269-315; Anne Secord, "Corresponding Interests: Artisans and Gentlemen in Nineteenth-Century Natural History," The British Journal for the History of Science 27, no. 4 (1994): 383-408; Gowan Dawson and Jonathan R. Topham, "Science in the Nineteenth-Century Periodical," Literature Compass 1 (2004): 1-11.

42 David E. Allen, Books and Naturalists (New York: Collins, 2010), 167.

${ }^{43}$ James Secord, Visions of Science. Books and Readers at the Dawn of the Victorian Age (Oxford: Oxford University Press, 2014); Pietro Corsi, "What do you mean by a periodical? Forms and functions," Notes and Records 70, no. 4 (2016): 325-41.

${ }^{44}$ Christophe Bonneuil, "The manufacture of species: Kew Gardens, the Empire, and the standardization of taxonomic practices in late nineteenth-century botany," in Instruments, Travel and Science Itineraries of Precision from the Seventeenth to the Twentieth Century, ed. Marie-Noëlle Bourguet, Christian Licoppe and H. Otto Sibum (London/New York: Routledge, 2002).

${ }^{45}$ Karl von Martius, "Robert Brown: an Eloge," The Annals and Magazine of Natural History 3rd series, no. 17 (1859): 321-31, on 327. 
than one colored illustration, the plates by Franz Bauer that accompany Brown's 1822 article are essentially technical, albeit extremely well executed.

Scientific publications generally did not exclude appeals to the aesthetic senses or emotions when the subject was exotic flora, especially tropical plants. ${ }^{46}$ The adjective "exotic" was first applied to non-native species, but in the seventeenth century it came to designate enticing otherness, rarity, or refinement. ${ }^{47}$ By the nineteenth century, exoticism had become a representation of otherness, mainly as brought from the colonial world, and this, in conjunction with the circulation of travel images and narratives, fascinated the European public.

\section{Creating a genus}

The case of Rafflesia is of particular interest when we consider Brown's work within the complex field of botany. The memoir in which he established the new genus was read at the Linnaean Society of London in 1820, preprinted in 1821, and published in the Transactions of the Linnean Society of London in $1822 .{ }^{48}$ As mentioned earlier, near the beginning of his paper, Brown transcribed an excerpt from a letter written by the late physician and naturalist Joseph Arnold, in which the latter described the plant itself and the circumstances under which it had been found. As in most accounts of so-called discoveries, any participation by the locals went unnoted, and the fact that the plant was unknown only to colonial authorities was downplayed. ${ }^{49}$ Expressions of amazement and wonder abound both in Arnold's letter and in the excerpt that Brown transcribed from a letter to Banks by Stamford Raffles, Governor of the East India Company's establishments in Sumatra. Raffles calls it "the largest and most magnificent Flower which, as far as we know, has yet been described." ${ }^{50}$ Arnold writes about penetrating the jungle, about the supporting role played by "Malay servants," and about the unprecedented size of the flower and its scent of "tainted beef." The narrative also mentions the presence of witnesses deemed qualified, who could prove the veracity of these facts: "Sir Stamford and Lady Raffles," along with "Mr. Palsgrave, a respectable man resident at Manna." 51

46 David Arnold, The Tropics and the Traveling Gaze. India, Landscape and Science, 1800-1856 (Seattle: University of Washington Press, 2006); Felix Driver and Luciana Martins, ed., Tropical Visions in an Age of Empire (Chicago and London: University of Chicago Press, 2005); and Roberto Ventura, Estilo tropical. História cultural e polêmicas literárias no Brasil (Sáo Paulo: Companhia das Letras, 1991).

47 Benjamin Schmidt, Inventing Exoticism. Geography, Globalism, and Europe's Early Modern World (Philadelphia: University of Pennsylvania Press, 2015); Ina Baghdiantz McCabe, Orientalism in Early Modern France Eurasian Trade, Exoticism, and the Ancien Régime (Oxford: Berg, 2008); Anne Goldgar, Tulipmania. Money, Honor, and Knowledge in the Dutch Golden Age (Chicago: University of Chicago Press, 2007).

48 Brown, "An Account of a new Genus of Plants."

${ }^{49}$ Barnard, "The Rafflesia in the Natural and Imperial Imagination."

${ }^{50}$ Brown, "An Account of a new Genus of Plants," 202.

51 Ibid., 203. 
Based on fragments of one flower and two buds, Brown devised general descriptions of the genus and species in Latin; he filled in gaps with suppositions and then explained and justified each possibility. Taking various alternatives into account, he also tried to establish "affinities" between the new Rafflesia genus and other known groups, such as Asarina and Passiflora. In his text, which was quite challenging to read, Brown attempted to explain where the various components of Rafflesia were located and the process of metamorphosis they had undergone, while he also offered general thoughts on "deviations" from "regular structures" that might possibly occur.

Brown's transcriptions and some of his own comments lend us insight into the kind of insecurity felt when the naturalists who first had contact with the flower tried to describe it using botanic criteria. Arnold, for example, wrote: "I have said nothing about the stamina; in fact, I am not certain of the part I ought to call stamina. If the moniliform cord surrounding the base of the pistil were sessile anthers, it must be a polyandrous plant; but I am uncertain what the large germen contained; perhaps there might be concealed anthers within it." ${ }^{52}$ After consulting the collections of the U.S. naturalist Thomas Horsfield, who lived in Java, many doubts remained. This sort of situation was inevitable, since botanical knowledge was not validated where the plants grew naturally but in European libraries, collections, and museums. Neither Brown nor Franz Bauer were ever in Sumatra or Java, but they would have the final word, and image, on Rafflesia.

In addition to his first memoir, Brown did another reading at the Linnean Society, on November 21, 1820, in which he incorporated information received from Arnold's successor, the young naturalist William Jack. According to Brown, Jack's letter had settled doubts about whether the plant was parasitic and about the discovery of the female flower. But several questions remained unanswered, such as whether the ovary was truly superior, as Jack claimed, and about the stigma:

Mr. Jack seems to refer both the corniculate processes of the disk, and the undivided limb of the column. These parts in the male flower have no evident papulose or secreting surface; for the hispid tips of the processes can hardly be regarded as such. But it is not likely that in the female flower they are equally destitute of this, which is the ordinary surface of a stigma; and it appears to me more probable that such a surface should be confined to a definite portion, probably the tips, of the corniculate processes, than that it should extend over every part of the apex of the column..$^{53}$

The difficulties encountered by Jack were inherent to fieldwork. When naturalists were in the field, it was challenging for them to arrive at precise descriptions and compare different

\footnotetext{
52 Ibid., 204.

${ }^{53}$ Brown, "Additional observations," 231.
} 
species, as was essential to plant classification. ${ }^{54}$ Although Brown had spent many years in the Pacific, he behaved like an armchair naturalist when it came to foreign plants, ignoring specific circumstances and approaching mainly through comparison. His analyses also made no reference to the plant's exoticism or exterior surroundings, even in cases where he had visited the place of origin, although references of this kind might have enlivened his accounts. For "an instructed mind," to use Martius's expression, Brown's narrative about the detection of hidden affinities seemed to unveil a web of mysteries, and for this it was fascinating.

Brown constructed his scientific authority among peers, within a restricted circle of specialists. This authority was recognized by broader forums, such as The Asiatic Journal and Monthly Register for British India and its Dependencies, sponsored by the East India Company. In its pages, we find a report on Rafflesia from 1820 that comments on the plant's amazing, exceptional features, extracted that same year from the periodical Annals of Philosophy. Entitled "Java," this short news item, which did not ascribe the find to anyone, called the reader's attention to "the most magnificent and singular flower," measuring up to three feet in circumference and "flat like a soup plate." ${ }^{55}$ The reader is also told that the plant had been sent to Banks and that Bauer had drawn one of the buds. Shortly after this news item appeared, the Asiatic Journal added a brief but well-structured abstract of Brown's memoir, including a description of the genus Rafflesia, likewise extracted from the Annals of Philosophy, ${ }^{56}$ which had in turn abstracted the memoir read by Brown at the Linnean Society. This was one of the pathways that a complex scientific paper like Brown's might take, that is, to be mediated by a scientific periodical more flexible and agile than the Transactions of the Linnean Society of London. ${ }^{57}$ An abstract plus Brown's name served as a mark of authority and something of a scientific "anti-conquest," to borrow Mary Louise Pratt's term. ${ }^{58}$

In the 1820s and 1830s, the most noteworthy reports on Rafflesia were Brown's paper and Franz Bauer's colored image, the latter reproduced in the story of Sir Thomas Stamford Raffles's life, released by his widow in $1830 .^{59}$ In 1835 , William Jackson Hooker published botanical

54 Dorinda Outram, Georges Cuvier. Vocation, science and authority in post-revolutionary France (Manchester: Manchester University Press, 1984); Lorelai Kury, “O naturalista Veloso," Revista de História 172 (2015): 243-77.

55 Anonymous, "Java," The Asiatic Journal and Monthly Register for British India and its Dependencies (1820): 374; Samuel F. Gray, “Botany (Java)," Annals of Philosophy 16, no. 92 (1820): 129-30.

${ }_{56}$ Anonymous, "Sumatra," The Asiatic Journal and Monthly Register for British India and its Dependencies (1820): 374-75; "Proceedings of Philosophical Societies," Annals of Philosophy 16, no. 93 (1820): 22526.

57 Topham, "The Scientific, the Literary and the Popular."

58 Mary Louise Pratt, "Narrating the anti-conquest," in Imperial Eyes: Travel Writing and Transculturation, 38-68 (London and New York: Routledge, 1992).

59 Sophia Raffles, Memoir of the Life and Public Services of Sir Thomas Stamford Raffles, F.R.S. Erc. (London: John Murray, 1830). 
descriptions and images referring to the work of the late Jack, in Malaysia. Around the same time as Brown, Jack had named the plant Rafflesia titan, but the name did not hold and the image published by Hooker was also not apparently successful. ${ }^{60}$ The Bauer brothers' images were also circulated by Brown himself, who presented them at scientific conferences in continental Europe. ${ }^{61}$

In 1821, Brown received another shipment from Raffles, this time a female specimen of Rafflesia arnoldii. He read a paper on the topic before the Linnean Society in 1834 but published it only in $1844 .{ }^{62}$ The flower appeared in five prints, based on monochrome watercolors by Franz Bauer (Figure 3). The paper also addressed the matter of the odd flower Hydnora africana, illustrated by Ferdinand Bauer. ${ }^{63}$ In the article, Brown voiced his admiration and affection for the Bauer brothers, who had by then passed away. While these representations of Rafflesia were very precise, they lacked the visual appeal of the first illustration (original dated 1818), ${ }^{64}$ which depicted the entire flower and included a prominent scale just below the image. In this case, the text left exoticism aside, focusing instead on morphological plant details, the authors who had investigated the topic, and conjectures about the affinities of the studied families.

60 William Jackson Hooker, "Descriptions of Malayan Plants by William Jack," in Companion to the Botanical Magazine, 1 (London: Edward Couchman, 1835). See Mabberley, "Robert Brown on Rafflesia."

${ }^{61}$ Lack, The Bauers, 363.

62 Mabberley, "Robert Brown on Rafflesia," 345.

${ }^{63}$ Robert Brown, "Description of the Female Flower and Fruit of Rafflesia arnoldi, with remarks on its Affinities, and an Illustration of the Structure of Hydnora africana," Transactions of the Linnean Society of London 19 (1844): 221-47.

${ }^{64}$ Paul Martyn Cooper, Images of Nature. The Bauer Brothers (Catalogue) (London: Natural History Museum, 2015), 55; Lack, The Bauers, 363. 


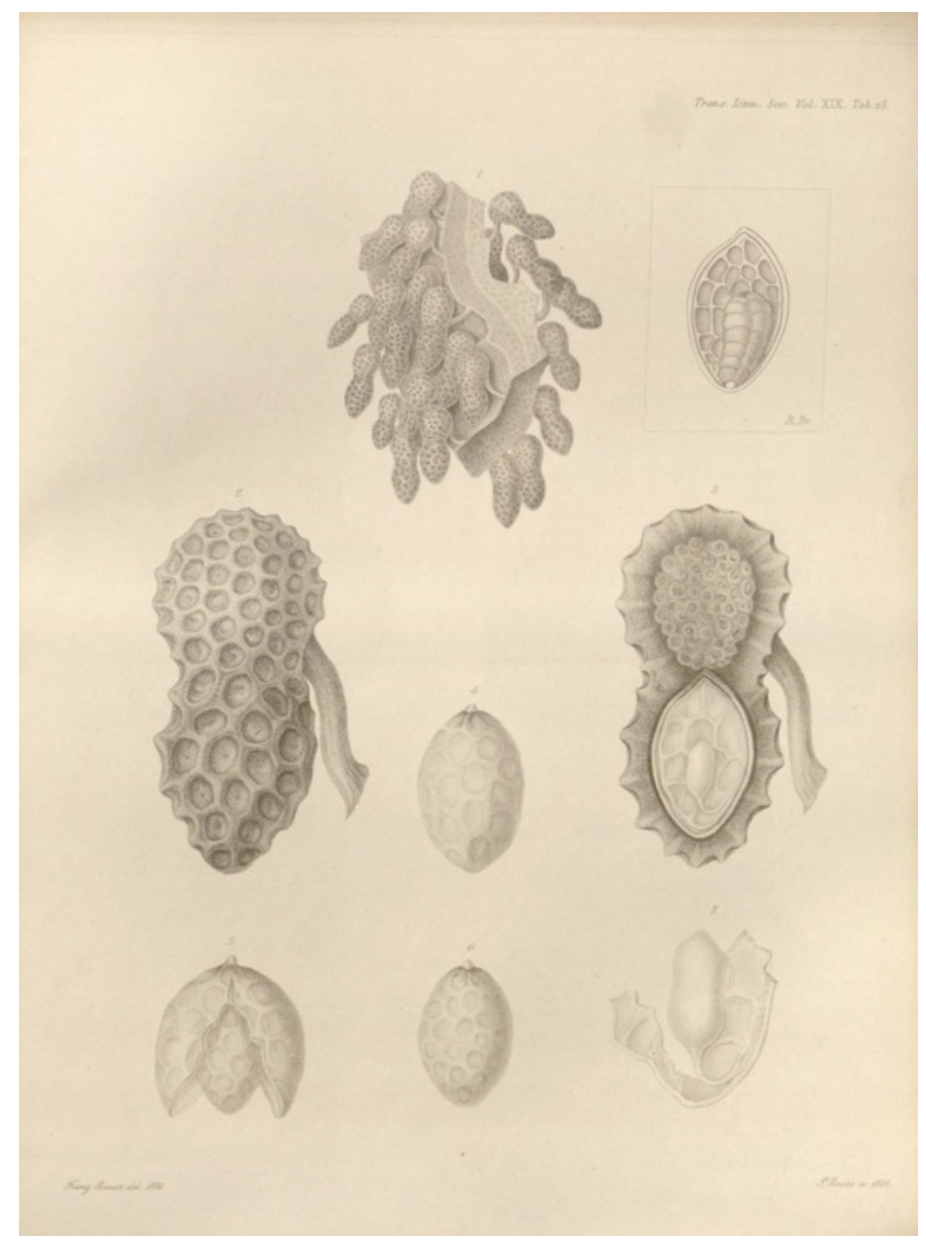

Figure 3. Rafflesia arnoldi, by Franz Bauer, plate XXV, in Brown, "Description of the Female Flower and Fruit." Image from the Biodiversity Heritage Library, contributed by Missouri Botanical Garden, Peter H. Raven Library, www.biodiversitylibrary.org

Much as in his first memoir, in 1844 Brown compared Rafflesia arnoldii with other genera and species in his effort to comprehend the plant's unusual development within the universe of flowering plants. He also tried to form a "natural family" encompassing the genera Rafflesia, Brugmansia, Hydnora, and Cytinus. He was only able to conduct his investigations and arrive at hypotheses because he could analyze plants from around the world. The key to understanding Rafflesia arnoldii might lie, he suggested, in analyzing a species from a completely different place, perhaps even from a different continent, like Hydnora africana, from southern Africa. Auguste de Saint-Hilaire, a French botanist and admirer of Brown's, described the identification 
of natural families as a discovery that transcended geographical borders; he also said related species were like brothers, who have an emotional bond even when separated. ${ }^{65}$

By this time, information and images of exotic plants were enjoying a much broader circulation and new audiences were forming among those interested both in the scientific achievements of Brown and his peers and in adventures and news on rare plants. Each new find in a different climate might be shared by various agents, vehicles, and publics. Elements of exoticism could still be felt in texts that were aimed at initiates and couched in technical language, that is, the novelty of the findings themselves, the special challenges reported by the botanists, and the rush to name plants and describe groups for the first time. The scientific authority of these dry narratives grounded publications and reports. With the aid of botanical theories, magnifiers, collections, herbaria, and books, Brown was able to organize exotic and native flora and thus detect affinities between plants. In his challenging, hermetic style, he eschewed exoticism as well as the travel account approach, opting instead to offer an identification of so-called "natural families" and groups on a global scale.

\section{Brown, Welwitsch, and Welwitschia}

Dolezal made it clear that certain extraordinary plants captivated nineteenth-century Europeans: "Of all plants collected over the course of the nineteenth century, during botanical explorations of the surface of the Earth, and which reached Europe, there were three that incited special interest among lay and learned alike: the Victoria regia, born in the streams of South America; the colossal flower of the Rafflesia arnoldii parasite, lacking leaves and stem, from the forests of the archipelago of eastern India; and Welwitschia, originating in the rainless deserts of Benguela." ${ }^{\prime 6}$

A comparison of the examples of Welwitschia and Rafflesia manifests the dynamics at play as Europe incorporated botanical knowledge of exotic plants. ${ }^{67}$ The Austrian botanist Friedrich

${ }^{65}$ Auguste de Saint-Hilaire, Réponse aux reproches que les gens du monde font à l'étude de la botanique (Orléans: Huet-Perdoux, 1811), 12.

${ }^{66}$ Helmut Dolezal, Friedrich Welwitsch Vida e Obra (Lisbon: Junta de Investigaçôes Científicas do Ultramar, 1974), 163.

${ }^{67}$ In the realm of classification systems, one person who should be mentioned is John Lindley, a central player in Victorian science culture. Lindley was the first professor of botany at University College London and served the (Royal) Horticultural Society for many decades. His publications targeted a specialist audience as well as amateurs and gardeners. From the perspective of systematics, he was one of those who introduced the natural method to England. See Ann B. Shteir, "Gender and 'Modern' Botany in Victorian England," Osiris 12 (1997): 29-38; Lynn Voskuil, "Victorian Orchids and the Forms of Ecological Society," in Strange Science: Investigating the Limits of Knowledge in the Victorian Age, ed. Lara Karpenko and Shalyn Claggett, 125-32 (University of Michigan Press, 2016); Peter F. Stevens, "On Amateurs and Professionals in British Botany in 1858 - J.D. Hooker on Bentham, Brown, and Lindley," Harvard Papers in Botany 2, no. 2 (1997): 125-32. 
Welwitsch, primarily responsible for the first news of Welwitschia, was a great admirer of Brown and of the work of Augustin and Alphonse de Candolle. The influence of Alexander von Humboldt can also be felt in his writings, field sketches, and watercolors. ${ }^{68}$

In his classification of plants, Welwitsch likewise used Jussieu's system, which was undergoing steady refinement, including improvements introduced by Brown himself.69 The system afforded the advantage of grouping plant forms according to their closest kinships, with an eye on internal organization. We find Brown's influence reflected in the tree of life sketch by Welwitsch (Figure 4), with its schematic grouping of plant forms. Despite refinements and adaptations to the system, Welwitsch found it quite problematic when studying his botanical collections from Africa, because he had attached the same collection number to plants gathered from different places and on different dates. ${ }^{70}$

${ }^{68}$ Sara Albuquerque and Silvia Figueirôa, "Depicting the Invisible: Welwitsch's Map of Travellers in Africa," Earth Sciences History 37, no. 1 (2018): 109-29; Friedrich Welwitsch, "Apontamentos FitoGeográficos sobre a Flora da Província de Angola na África Equinocial, servindo de Relatório Preliminar àcerca da exploração botânica da mesma província executada por Ordem de Sua Majestade Fidelíssima pelo Dr. Welwitsch," Annais Conselho Ultramarino, Parte Não Official (Apontamentos), sér. I (1858): 527-80.

${ }^{69}$ Dolezal, Friedrich Welwitsch Vida e Obra, 111.

${ }^{70}$ A collection number is usually a unique number assigned to a species collected on a certain date and in a certain place. However, Welwitsch assigned the same collection number to plants that he suspected of belonging to the same species but were in different stages of development (flowering or fruiting, for instance) and which later proved to belong to different species. See Sara Albuquerque, Richard Kenneth Brummitt and Estrela Figueiredo, "Typification of names based on the Angolan collections of Friedrich Welwitsch,” Taxon 58, no. 2 (2009): 641-46. 


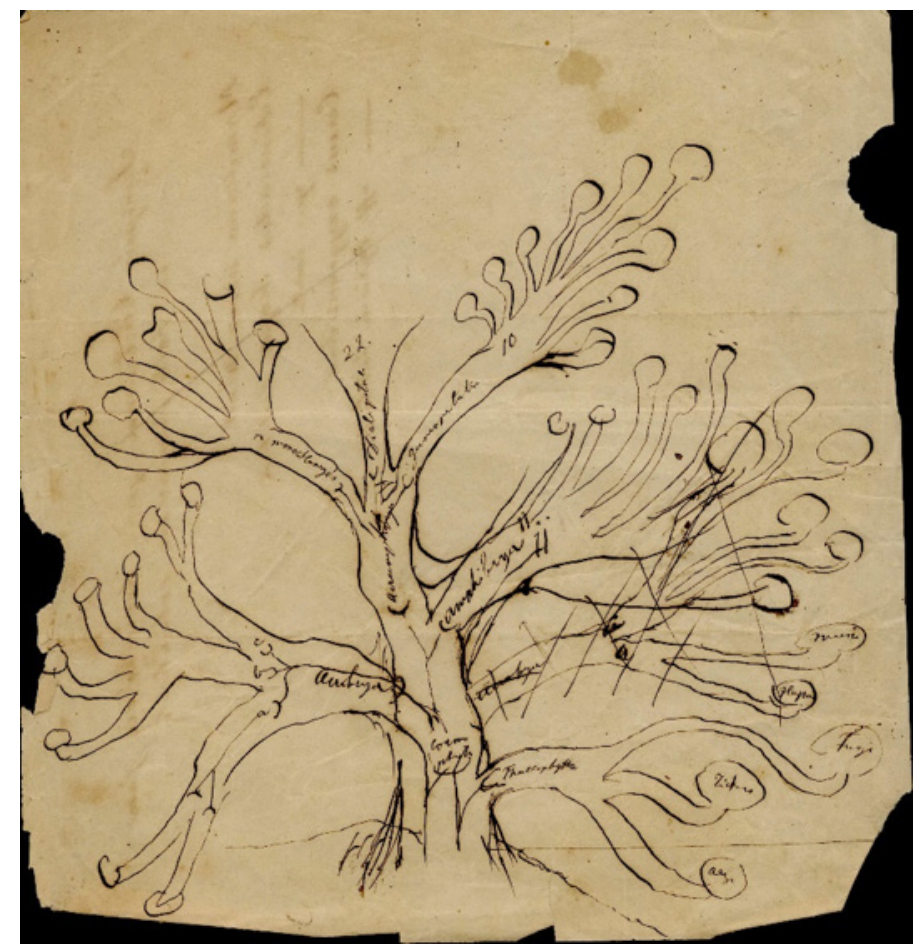

Figure 4. Welwitsch's sketch Tree of Life, Box.1, fl41f (MUHNAC/Museums of the University of Lisbon Historical Archives(C). Reproduced with permission from the National Museum of Natural History and Science, University of Lisbon.

In July 1839, traveling through the Württemberg Botanical Travel Association, Unio Itineraria, ${ }^{71}$ Welwitsch arrived in Portugal, where he met Brown in August 1841. They spent three days together exploring the Zebro Valley, a swampy region south of the Tagus River. As a symbol of their friendship and time together, Brown offered Welwitsch a pocket magnifier, which the Austrian would later proudly exhibit to colleagues and visitors. ${ }^{72}$ Yet Welwitsch never had a chance to trade ideas about the peculiar plant with his colleague and idol, because the Scotsman died on 10 June 1858, at the age of 84, almost one year before Welwitsch saw the curious plant for the first time. The Austrian's encounter with this plant from the Moçâmedes Desert, in what is now Namibia, took place on 3 September 1859, near the end of the Iter Angolense $^{73}$ expedition (1853-1860).

\footnotetext{
${ }^{71}$ The Württemberg Botanical Travel Association, Unio Itineraria, was an association that sent botanists on expeditions to various places around the world so they could collect botanical specimens, which could later be sold to members. Welwitsch belonged to this association and through it went on an expedition to Portugal and some of its islands.

72 Dolezal, Friedrich Welwitsch Vida e Obra, 46.

${ }^{73}$ Johann Müller et al., "Welwitschii Iter Angolense," Journal of Botany, British and Foreign 2 (1864): 326-39 and Journal of Botany, British and Foreign 3 (1865): 33-5 and 110-15.
} 
According to Dolezal, Welwitsch knelt down when he saw the plant, because he simply could not believe his eyes. ${ }^{74}$

Welwitsch recounted bits and pieces of his first sighting of the plant in his notes, which can be found in Lisbon, Portugal, at the National Museum of Natural History and Science (Museu Nacional de História Natural e da Ciência, University of Lisbon) (Figure 5). We can sense Welwitsch's enthusiasm over his finding; the text is peppered with exclamation points and his style veers subtly towards a degree of excitement, contrasting with the tone of his other field notes. Certain terms stand out, like "elephant ear," perhaps borrowed from the localsafter all, while the species was new to Western science, it had long been a routine part of the landscape for desert inhabitants (Figure 6). Another noteworthy reference is to "Tumboa," which, according to Welwitsch, drew its inspiration from "Tumbo," a local name. ${ }^{75}$

Figure 5. Notes produced by

Welwitsch on September 3, 1859

(MUHNAC/Museums of the University of Lisbon Historical Archives(@). Reproduced with permission from the National Museum of Natural History and Science,

University of Lisbon. Note: words

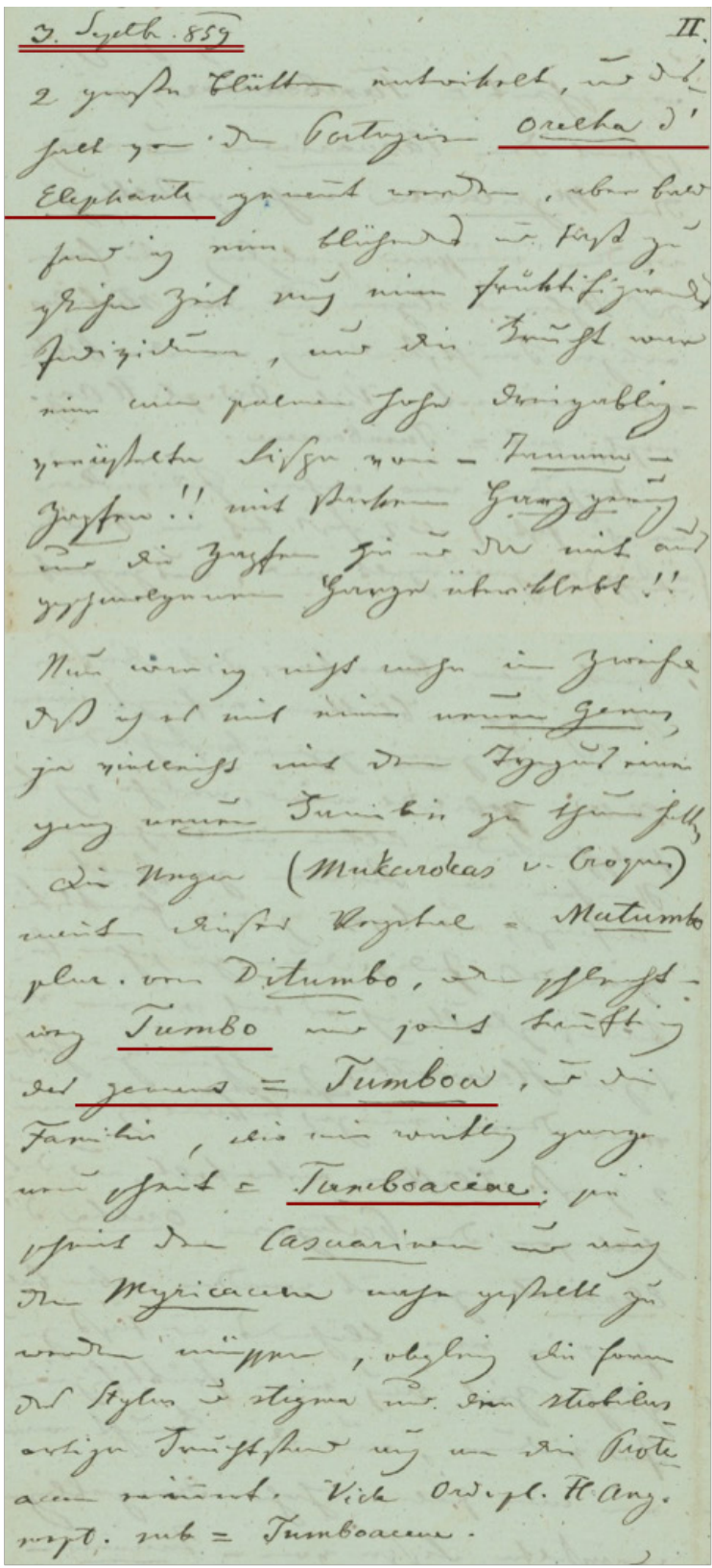
marked by the authors.

\footnotetext{
${ }^{74}$ Dolezal, Friedrich Welwitsch Vida e Obra.

75 Joseph Dalton Hooker, "On Welwitschia, a new Genus of Gnetaceae," Transactions of the Linnean Society of London 24, no. 1 (1863): 1-48, on 2.
} 


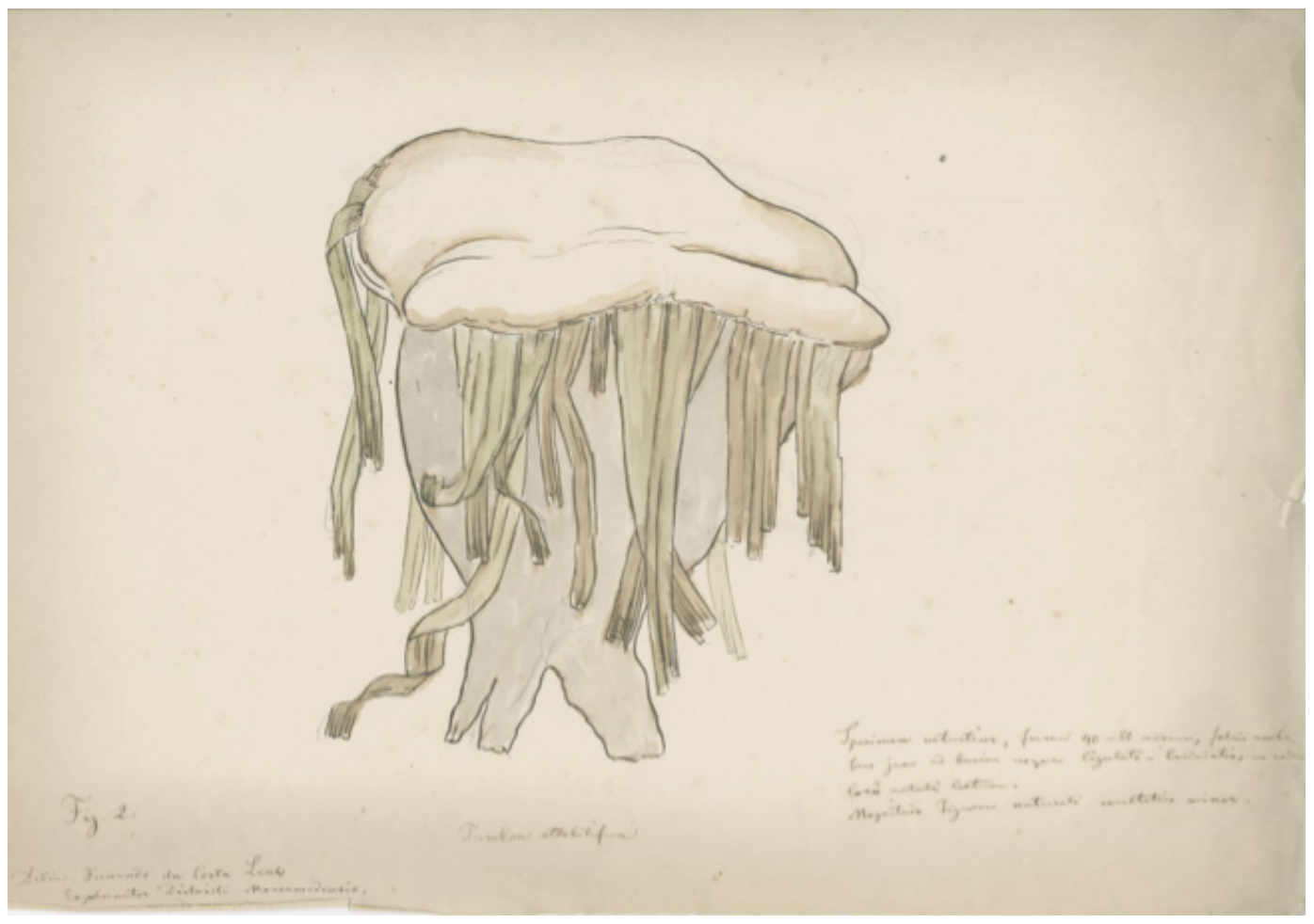

Figure 6. "Drawing of Tumboa strobilifera" Tumboa strobilifera Welw. ex Hook. f. is a synonym of Welwitschia mirabilis Hook. f. This manuscript was produced by Friedrich Welwitsch during the Iter Angolense, circa 1859 (PT-MUL-FW-01-075, MUHNAC/Museums of the University of Lisbon Historical Archives(C). Reproduced with permission from the National Museum of Natural History and Science, University of Lisbon. ${ }^{76}$

The story might have turned out differently. Like many other Europeans, Thomas Baines also explored the area, and while he mentioned the "bulbous plant with four leaves," he did not describe it scientifically; furthermore, the drawings he did were incorrect and therefore lacked scientific validity. ${ }^{77}$ According to Joseph Dalton Hooker, "Mr Baines's sketch is, however, more artistic than scientific" (Figures 7 and 8 ). ${ }^{78}$ Baines's sketches were indeed picturesque in style.

\footnotetext{
${ }^{76}$ Albuquerque and Figueirôa, "Depicting the Invisible," 111.

77 Thomas Baines, Explorations in South-West Africa: Being an Account of a Journey in the Years 1861 and 1862 from Walvisch Bay, on the Western Coast, to Lake Ngami and the Victoria Falls (London: Longman, Green, Longman, Roberts, \& Green, 1864), 24. Welwitschia has only two leaves, which grow continuously and can reach up to four meters in length. See Chris Bornman, Welwitschia (Cape Town: Struik, 1978).

${ }^{78}$ Hooker, "On Welwitschia, a new Genus of Gnetaceae," 3. John Thomas Baines was an English artist and explorer who made expeditions to Australia and Africa. Because of his previous work in Australia, he was invited to accompany David Livingstone on the 1858-1859 Zambezi expedition. For more information on Baines, see David Goyder, "Localities of plants collected by Thomas Baines on the Baines-Chapman expedition to Lake Ngami and Victoria Falls 1861-1863," Kew Bulletin 71, no. 4
} 
Pictorial representations of the natural world became more common beginning in the late eighteenth century and occupied increasing space in illustrated publications in the latter half of the nineteenth. ${ }^{79}$

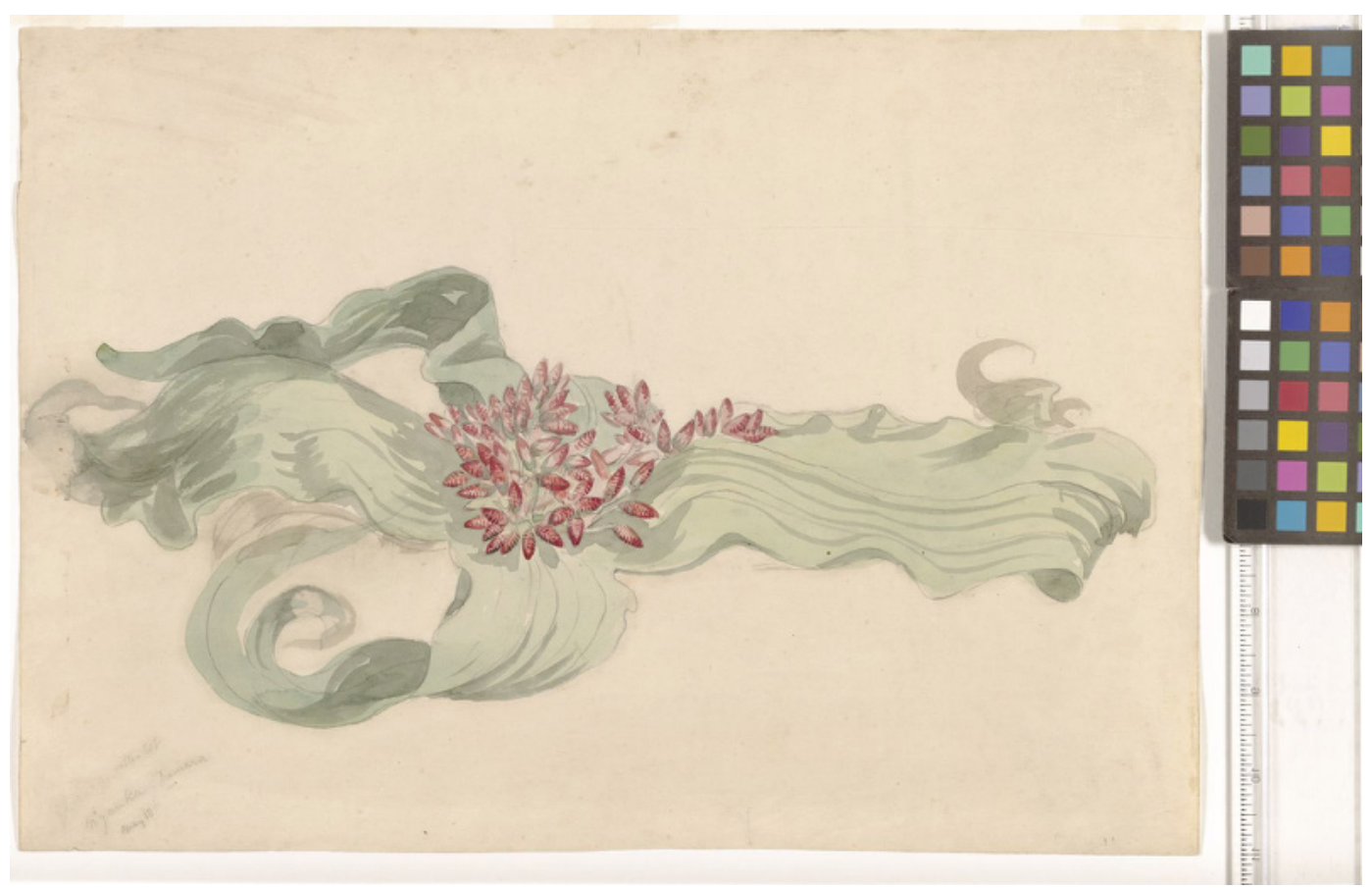

Figure 7. Welwitschia mirabilis - Watercolour and pencil field sketch, by Paul Little, ORBG Kew. Reproduced with permission from the Royal Botanical Garden, Kew. ${ }^{80}$

(2016): 1-8; Jane Carruthers and Marion I. Arnold, The Life and Works of Thomas Baines (Vlaeberg, South Africa: Fernwood Press, 1995); Lowri Jones, "Local knowledge \& indigenous agency in the history of exploration: studies from the RGS-IBG collections." (PhD thesis, Department of Geography, Royal Holloway, University of London, 2010).

${ }^{79}$ Claudio Greppi, "'On the Spot': Traveling Artists and the Iconographic Inventory of the World, 1769-1859," in Tropical Visions in an Age of Empire, ed. Felix Driver and Luciana Martins (Chicago and London: University of Chicago Press, 2005), 23-42.

80 "Welwitschia mirabilis Hook.f." http://powo.science.kew.org/?q="Welwitschia mirabilis, accessed November 30, 2020. 


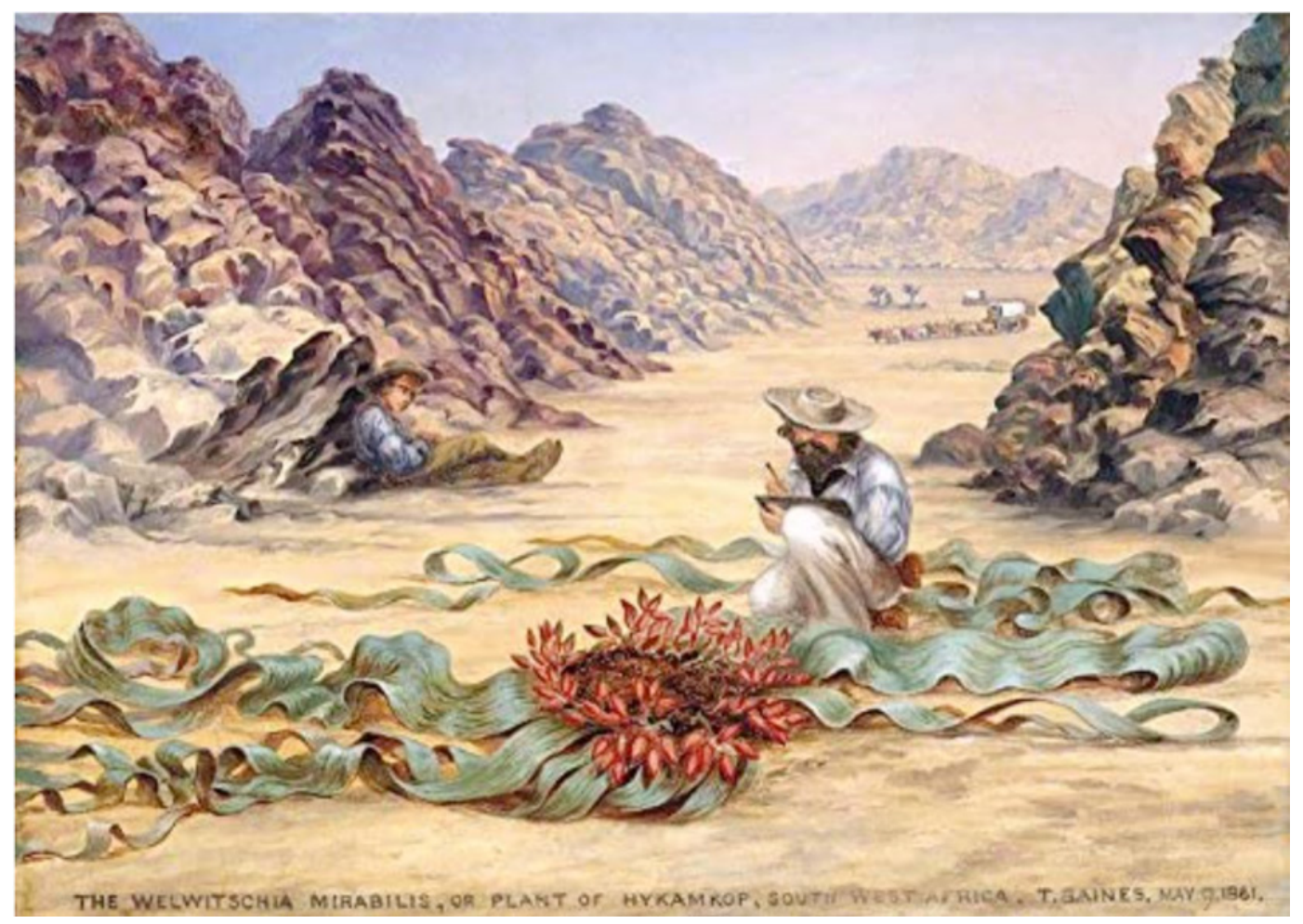

Figure 8. 'The Welwitschia mirabilis', oil on canvas, by Thomas Baines, April 1867.

Library Collections: Baines, Thomas. Reproduced with permission from the Library \& Archives at Royal Botanic Gardens, Kew. ${ }^{81}$

We see in figure 8 how Baines depicted himself sketching the desert plant in the field, a common practice in his work. ${ }^{82}$ While Baines sought pictorial precision in his images, his drawings were not faithful to Welwitschia in botanical terms, as stated by Hooker. ${ }^{83}$

Unlike Baines, Welwitsch was a botanist. He was awestruck by the "strange desert plant" and quick to recognize it as a botanical finding not yet described scientifically. According to his biographer, Dolezal, "Welwitsch was amazed, a little incredulous, towards this rare plant, fearing that it was a hallucination of his senses." ${ }^{44}$ His representation of Welwitschia was scientifically accurate and came accompanied by a provisional scientific name, as well as a description in Latin (Figure 6).

81 "The Welwitschia mirabilis," https://plants.jstor.org/stable/10.5555/al.ap.visual.kbai00000024, accessed November 30, 2020

82 Jones, "Local knowledge \& indigenous agency in the history of exploration."

${ }^{83}$ Michael Stevenson, ed., Thomas Baines: An Artist in the Service of Science in Southern Africa (London: Christie's, 1999); Hooker, "On Welwitschia, a new Genus of Gnetaceae."

${ }^{84}$ Dolezal, Friedrich Welwitsch Vida e Obra. 
While the find was made in September 1859, official news of the plant only reached Europe via a letter from Welwitsch to Sir William Jackson Hooker, Joseph Dalton Hooker's father, dispatched in August 1860 and later published in the Journal of the Proceedings of the Linnean Society. ${ }^{85}$ In his letter, Welwitsch said he would be taking "some specimens of this wonderful plant to Europe, together with flowers and fruit, and [would] thus have the opportunity of presenting it in natura." ${ }^{\prime 6}$ In the same letter, the botanist described the plant in detail: "a dwarf tree ... particularly remarkable . . always retained the two woody leaves which it threw up at the time of germination. . . The entire plant looks like a round table." This was followed by a more technical description in Latin, in keeping with botanical norms. ${ }^{87}$ Welwitsch closed the letter with a reference to a species from the family Rafflesiaceae; he said he was unable to identify it but had collected male and female specimens, which he would send off, "preserved in spirits." 88

In the Western world, Tumboa became known as Welwitschia mirabilis, the famous plant of the Namib Desert; it was labeled one of the world's ugliest plants but also considered the most wondrous. According to Joseph Hooker, "since the discovery of the Rafflesia arnoldii, no vegetable production has excited so great an interest as the subject of the present memoir." ${ }^{9}$ Hooker's paper "On Welwitschia, a new Genus of Gnetaceae" (1863) reconciled Welwitsch's descriptions with the specimens sent to Europe by him and other naturalists on the African continent, such as Baines and Joachim Monteiro. ${ }^{90}$ Baines's specimens reached Kew in the autumn of 1861, months before those sent by Welwitsch. However, the box holding Baines's samples was not accompanied by any letter, only "some admirable colored drawings illustrating the vegetation of that country ... and a sketch of a plant which I at once recognized as generically, if not specifically, identical with that discovered by Dr. Welwitsch." ${ }^{11}$

After arriving in Portugal, Welwitsch wrote to Alphonse de Candolle, once again describing Tumboa in his letter: "This is assuredly one of the most extraordinary plants that exist in

${ }^{85}$ Friedrich Welwitsch, "Extract from a letter, addressed to Sir William J. Hooker, on the botany of Benguela, Mossamedes, \&C, in Western Africa," Journal of the proceedings of the Linnean Society. Botany 5 (1861): 182-86

86 Ibid., 185.

${ }^{87}$ Ibid.

${ }^{88}$ Ibid., 187.

${ }^{89}$ Hooker, "On Welwitschia, a new Genus of Gnetaceae," 1.

90 Welwitsch, "Extract from a letter, addressed to Sir William J. Hooker," 185-86; Hooker, "On Welwitschia, a new Genus of Gnetaceae," 4; Joachim John Monteiro, Angola and the River Congo, Volume I (London: Macmillan, 1875). The specimens dispatched by Welwitsch, Baines, and Monteiro are now held by the Economic Botany Collection of the Royal Botanic Gardens, Kew. "Economic Botany Collection Database," https://www.kew.org/science/collections-and-resources/collections/ economic-botany-collection, accessed April 13, 2020.

${ }^{91}$ Hooker, "On Welwitschia, a new Genus of Gnetaceae," 3. The drawings by Thomas Baines can still be found at Royal Botanic Gardens, Kew. 
intertropical Africa; and notwithstanding certain resemblances of structure with Coniferae and Casuarinaceae, and even with Proteaceae, I believe we have here the type of a new family." This strange desert plant aroused a great deal of interest in the scientific community because it combined very different plant characteristics in one sole plant. Charles Darwin's interest is a notable example of this. Although Welwitsch did not correspond directly with Darwin, Hooker and Darwin mentioned Welwitsch's work in their correspondence, including his discovery of Welwitschia: "I have looked in Lindley about Gnetum; what a curious form your new one must be-what a fine living fossil, preserved from past times." ${ }^{33}$

We could argue that Welwitsch sent correspondence to his colleagues as a strategy for disseminating his work, given that a letter might take some time to reach its destination but would do so in less time than it would take to publish a paper. Since Welwitsch's letters contained official descriptions (i.e., in Latin), they served to validate his work, even if the correspondence did not constitute an actual publication. Furthermore, when he exchanged letters about Tumboa with William Hooker and other colleagues, he was "guaranteeing" his scientific authority in regard to this "discovery," even if Baines had been quicker to dispatch his specimens. ${ }^{94}$ Although Welwitsch was the collector, it was Joseph Hooker who eventually published on the desert plant and named it Welwitschia mirabilis, in honor of the Austrian botanist. Hooker described Welwitschia in these words:

the most wonderful, in a botanical point of view, that has been brought to light during the present century; for an attentive study of the structure of its vascular system, as well as of its reproductive organs, and of the evidence we have of its functional peculiarities and mode of development, will disclose in all these points very singular anomalies, which even appear in some instances subversive of theoretical axioms hitherto considered as fundamental in Botany. ${ }^{95}$

\section{Explorers, botanists, and artists}

While on the expedition, Welwitsch produced drawings and watercolors of landscapes, in addition to collecting natural history items. Like other naturalists of the day, Welwitsch presumably did not want to be known as an artist and was therefore discreet about his artistic abilities. ${ }^{96}$ On the other hand, Baines was an artist per se and his drawings were an expression

${ }^{2}$ Letter from Lisbon, April 20, 1861, in Hooker, “On Welwitschia, a new Genus of Gnetaceae," 2.

93 "Darwin Correspondence Project," Letter no. 3296, http://www.darwinproject.ac.uk/DCPLETT-3296, accessed June 3, 2020.

${ }^{44}$ Hooker, "On Welwitschia, a new Genus of Gnetaceae," 3.

95 Ibid., 3-4.

96 Albuquerque and Figueirôa, "Depicting the Invisible," 113; Leila Koivunen, "Africa on the spot and from the distance: David Livingstone's missionary travels and nineteenth-century practices of illustration," Scottish Geographical Journal 129, no. 3-4 (2013): 194-209, on 196. 
of his curiosity and the pleasure he derived from observing nature. ${ }^{97}$ Because of his earlier work in Australia, he was invited to accompany David Livingstone on the 1858-1859 Zambezi expedition. ${ }^{98}$ But temperamental incompatibility soon led Livingstone to dismiss Baines, who then embarked on a southwest African expedition (1861-1862), along with Chapman, in hopes of re-establishing his reputation as an explorer. ${ }^{99}$ According to Michael Godby, "Chapman's Travels in the Interior of South Africa (1868) and Baines's Explorations in South-West Africa (1864) provide rare accounts of different perspectives on the same trip," with Chapman using photography and Baines using painting to document the expedition. ${ }^{100}$ Baines did a drawing of the botanical novelty early in the southwest Africa expedition. ${ }^{101}$ Chapman's photography influenced Baines, motivating him to include elements that would make his drawings seem more real. ${ }^{102}$ We can infer Baines's desire to compete with photography from his illustration of Welwitschia mirabilis, where he depicts himself in the act of drawing. The wagon train in the background hints at the distance he had to travel to do the illustration, once again reinforcing the veracity of his record. ${ }^{103}$

Contemporary journals show how these mysterious, atypical plants drew the interest not only of scientists but also of the public at large. For example, the paper by Joseph Hooker (1863) caught the attention of The Illustrated London News, which published an article entitled "The Welwitschia" in its Scientific News section. ${ }^{104}$ The Norfolk News made mention of the "extraordinary tree" described during a "lecture on botany" given by Professor Daniel Oliver in London. ${ }^{105}$ In addition to mentioning Welwitsch and Baines and to noting that it had been an "almost simultaneous discovery," the journalist also suggested that Oliver should have revised his rather technical talk to suit a "general audience." Both articles described the plants and their characteristics using complex terms like "Coniferae" and "monocotyledons," appropriate to an audience with an above-average level of scientific literacy.

It was a time of greater exchange between specialized technical work and news aimed at a more general public keen on "exoticism." While the world was intrigued by this peculiar plant, the Portuguese government that funded the Iter Angolense expedition was apparently not, quite

${ }^{97}$ Marion Arnold, "An Artist who Travelled: Thomas Baines," South African Historical Journal 23, no.1 (1990): 134-46, on 134.

${ }^{98}$ Helen Luckett, “Thomas Baines: 1820-1875," The Geographical Journal 141, no. 2 (1975): 252-58, on 256.

99 Michael Godby, "The Interdependence of Photography and Painting on the South West Africa Expedition of James Chapman and Thomas Baines, 1861-62," Kronos 27 (2001): 30-42 on 31.

100 Godby, "The Interdependence of Photography," 30.

101 Ibid., 32-3.

102 Ibid., 33.

103 Ibid.

104 Anonymous, "The Welwitschia," The Illustrated London News, Saturday, 11 April 1863, 23.

105 Anonymous, "Welwitschia mirabilis," Norfolk News, Saturday, 31 January 1863. 
likely because Welwitschia was of no practical use, with the exception that its cones could be eaten raw or roasted by the locals of the Namib desert. ${ }^{106}$ The Portuguese government also evinced its disinterest in the plant by failing to send a specimen to the 1862 exhibition in London. In fact, Welwitsch did not mention Welwitschia in either "Apontamentos preliminares de varios objectos de Angola, próprios à exposição de Londres" (Preliminary notes on various objects from Angola, suitable for the London exhibition) ${ }^{107}$ or Synopse explicativa (Explanatory synopsis). ${ }^{108}$ Because of the plant's high concentration of salts, neither its leathery leaves, impregnated with calcium oxalate, nor its disc-shaped stalk could serve as animal feed or firewood. However, while Welwitschia mirabilis served no apparent purpose, it would later prove to have scientific value, when the theory of plate tectonics found support with the discovery of Welwitschia fossils (Priscowelwitschia austroamericana) in South America. ${ }^{109}$

In terms of plant description, just as Brown had described Arnold's Rafflesia and called it Rafflesia arnoldii in his honor, something similar happened with Tumboa. Joseph Hooker, director of the Royal Botanical Gardens, Kew, published the desert plant as Welwitschia mirabilis, paying tribute to Welwitsch and adding the epithet "mirabilis," which means "wondrous" or "amazing" in Latin. ${ }^{110}$ Although it was later changed to bainesii to honor both Welwitsch and Baines, mirabilis is now the accepted epithet.

To be an explorer required not only a high degree of professionalization but also the mastery of diverse subjects. ${ }^{111}$ However, one's dedication to each specific duty or task could vary. Although the Portuguese government issued Welwitsch specific instructions about assessing Angola's

106 Patricia Craven and Christine Marais, Namib Flora: Swakopmund to the giant Welwitschia via Goanikontes (Windhoek, Namibia: Gamsberg MacMillan Publishers, 1986).

${ }^{107}$ Friedrich Welwitsch, "Apontamentos preliminares de varios objectos de Angola, proprios à exposição de Londres, cuja acquisiçáo poderá levar alguma demora, e que por isso convem recommendar-se desde já os cuidados das respectivas auctoridades e Angola," Diário do Governo (1861): 185-87.

108 Friedrich Welwitsch, Synopse explicativa das amostras de madeiras e drogas medicinaes e outros objectos mormente etnographicos colligidos na provincia de Angola enviados á exposição internacional de Londres em 1862 incluindo os que foram offerecidos ao gabinete pharmacologico (Lisbon: Imprensa Nacional, 1862).

${ }^{109}$ David L. Dilcher, Mary E. Bernardes-De-Oliveira, Denise Pons and Terry A. Lott, "Welwitschiaceae from the Lower Cretaceous of northeastern Brazil," American Journal of Botany 92, no. 8 (2005): 1294310; David L. Dilcher, Mary E. Bernardes-De-Oliveira, Denise Pons and Terry A. Lott, "Welwitschiaceae from the Lower Cretaceous of northeastern Brazil - Erratum," American Journal of Botany 92, no. 12 (2005): 1957. In 1915, Alfred Wegener put forth his theory of "continental drift" in Die Entstehung der Kontinente und Ozeane (The Origin of Continents and Oceans), arguing that the east coast of South America had once been joined to the west coast of Africa. See Alfred Wegener, The Origin of Continents and Oceans (New York: Dover, 1966); Naomi Oreskes, Plate Tectonics: An Insider's History of the Modern Theory of the Earth (Boulder and Oxford: Westview Press, 2003).

${ }^{110}$ Hooker, "On Welwitschia, a new Genus of Gnetaceae."

111 Ana Simóes, Ana Carneiro and Maria Paula Diogo, "Travels of Learning," in Travels of Learning: A Geography of Science in Europe, ed. Ana Simóes, Ana Carneiro and Maria Paula Diogo (Heidelberg: Springer, 2003), 3. 
natural resources across all regions of the country, he dedicated most of his time to collecting and organizing specimens and spent longer periods in certain regions. These professionals were expected to observe, survey, record data (meteorology, geographical coordinates, etc.), collect specimens, write detailed descriptions of fauna and flora, gather commercial and political information, do sketches, write reports, and publish results. ${ }^{112}$ An explorer's success also depended on his "preparation, training, technical skills, and support." 113 All these procedures, which both Welwitsch and Baines employed, were "hallmarks of the Victorian explorer," who was expected to follow the rigorous instructions described in manuals and guides. ${ }^{114}$ Conversely, Baines was an "explorer-artist" who collected specimens, albeit smaller amounts; spent less time in the localities where he collected; and was more focused on sketching landscapes of the African continent. ${ }^{115}$ In addition, Baines published his adventures and reached a wider audience, unlike Welwitsch, who did not write about his expeditions and only published for a professional, specialized audience. ${ }^{116}$ In this respect, Welwitsch's approach was quite similar to Brown's, that is, very technical. Although both explorers had gone on expeditions, they were not concerned with publishing for a less scientific, and specialized audience, a tool that could have been used to disseminate their work, like Baines or Livingstone. ${ }^{117}$

Although Baines's drawing of Welwitschia was not scientifically accurate and he seems to have further exoticized the exotic, he also did botanical illustrations that included precise drawings of cross-sections, for example. ${ }^{118}$ Baines, unlike Welwitsch, published and documented his expeditions in hopes of reaching a wider audience. Through his work, Baines wanted to help his audience assign these remote lands a recognizable place in their imaginations, ${ }^{119}$ effectively

\footnotetext{
112 Richard Francis Burton, Zanzibar: City, Island and Coast (London: Tinsley, 1872).

${ }^{113}$ Dane Kennedy, "Professionals" in The Last Blank Spaces: Exploring Africa and Australia (Cambridge, Massachusetts: Harvard University Press, 2013), 64.

${ }_{114}$ Michael F. Robinson, "Introduction" in The Lost White Tribe: Explorers, Scientists, and the Theory That Changed a Continent (Oxford: Oxford University Press, 2016), 7; Arthur MacGregor, Naturalists in the Field: Collecting, Recording and Preserving the Natural World from the Fifteenth to the Twenty-First Century (Leiden \& Boston: Brill, 2018), 16.

${ }^{115}$ Michael Stevenson, ed., Thomas Baines: An Artist in the Service of Science in Southern Africa, (London: Christie's, 1999). “The Herbarium Catalogue, Royal Botanic Gardens, Kew," http://www.kew.org/ herbcat, accessed June 8, 2020.

116 Thomas Baines, Journal of a residence in South Africa, ed. R. F. Kennedy (Cape Town: Jan Van Riebeeck Society, 1961-64); Thomas Baines, Explorations in South West Africa: being an account of a journey in the years 1861 and 1862 from Walvisch Bay on the western coast, to Lake Ngami and the Victoria Falls (London: Longman, Green, Longman, Roberts \& Green, 1864); Thomas Baines, The gold regions of South Eastern Africa (Charing Cross, London \& Port Elizabeth, Cape Colony: Edward Stanford \& J.W.C. Mackay, 1877).

117 Koivunen, "Africa on the Spot."

118 Godby, "The Interdependence of Photography," 33.

${ }_{119}$ Lindy Stiebel, "Creating a Landscape of Africa: Baines, Haggard and Great Zimbabwe," English in Africa 28, no. 2 (2001): 123-33, on 123.
} 
encouraging a particular idea of exoticism. ${ }^{120}$ It should be noted that he also used paintings and publications to advertise his work, with a view to attaining further research funding. ${ }^{121}$ Welwitsch, on the other hand, published for two particular audiences, the scientific public and the Portuguese government, who financed the expedition and required the filing of official reports. In the realm of artistic skill, he was, as mentioned earlier, very reserved, and never published his drawings. Baines, on the other hand, was an artist who documented his expeditions through publication, visually organizing exotic landscapes. ${ }^{122}$

\section{Final considerations}

Throughout the nineteenth century, Brown, Hooker, Welwitsch, and many other botanists employed a method for understanding global flora that emphasized affinities between plants rather than their unique characters, in this way contributing to a normalization of anomalous plants. On the other hand, the travel literature and serial publications that were read by a broader public framed these new plants as sources of awe and wonder. Yet these two types of reporting were not without interconnections. To the contrary, a variety of scientific publications helped shroud extra-European vegetation-and especially tropical plants—in an atmosphere of mystery and exoticism.

Some of the travel narratives written by these naturalists presented scenes of adventures and imagetic descriptions of wondrous, paradisiacal, or inhospitable places and might also be accompanied by expressive illustrations, such as the drawings by Thomas Baines. Much variation can be found in works devoted specifically to botany, which sometimes targeted a broad public with an interest in local and exotic flora. Hooker, in a clever appeal to a portion of European readers keen on natural history, collaborated with artists like the famous illustrator Walter Hood Fitch and with John Nugent Fitch, who did the prints of Welwitschia featured in On Welwitschia, a new Genus of Gnetaceae, published in 1863.

Specialized botany, with its dry style, hermetic vocabulary, and frequent call to have a magnifier in hand, was increasingly non-accessible to the uninitiated. Natural history theory and methods were undergoing a clear process of internationalization. In addition to Latin, it was important to have a mastery of French, the era's scientific lingua franca. Research into exotic flora also required access to collections of hard-to-obtain plants and the ability to receive shipments from collectors abroad.

\footnotetext{
${ }^{120}$ Stiebel, "Creating a Landscape of Africa," 123.

${ }^{121}$ Godby, "The Interdependence of Photography," 41.

${ }^{122}$ Ibid., 39.
} 
All this endowed the work of these naturalists with scientific authority, a vital element in lending legitimacy to news about exotic plants, even when the publisher of this news was a more generalized periodical. In other words, there was ongoing dialogue between these different types of accounts.

In his work, Brown found himself in much the same place as other botanists of his day, grappling with the fact that Linnaean botany was imploding, as an overwhelming number of unknown plants were identified in conquered territories, colonies, and areas of recent scientific exploration. While the so-called natural method did not offer the same ease as the Linnaean system, it allowed global flora to be mapped while encompassing strange new "discoveries" and exceptions within the universe of morphological possibilities produced during plant development. New observation procedures enabled the detection of affinities and hidden kinships between plant groups. More than ever before, botany aspired to arrive at universally applicable methods. Even naturalists who had traveled to lands largely unknown to the field of European botany behaved like armchair scientists since, in terms of systematics, what mattered to them was pinpointing morphological features that would render exotic and anomalous plants familiar through comparison. Botany sought to ascertain the true identities of these species, and the natural method afforded European knowledge they considered more relevant, and potentially more valuable, than the type of knowledge possessed by the populations who actually dwelled among the living specimens.

The dialogue between scientific texts and the media that targeted a non-specialized public entailed some degree of exoticism, but rather than focusing on adventures or sensorial aesthetics, naturalists used the natural method to reduce bizarre forms to botanical normalcy. Thanks to the discovery of hidden affinities, herbaria that centralized samples from around the world, greenhouses that simulated a range of climates, and up-to-date libraries, colonial expansion made flora global. 


\section{Acknowledgements}

Special thanks are due to Ana Isabel Correia (MUHNAC, LISU), Alexandra Lucas (MUHNAC, LISU), and Branca Moriés (MUHNAC, IICT). The authors would also like to thank Marta Lourenço (MUHNAC) for establishing the link between them through the Project "Riscar o Mundo" (Calouste Gulbenkian Foundation, Portugal, ref. 138507), without which this exchange would not have been possible.

\section{Competing interests}

The authors have declared that no competing interests exist.

\section{Funding}

Lorelai Kury's research was funded by the Conselho Nacional de Pesquisa (CNPq). Sara Albuquerque's research at the archives and herbaria at MUHNAC was possible thanks to funding from FCT (Fundação para a Ciência e a Tecnologia, Portugal, ref. SFRH/BPD/108236/2015). The research for this article relied on the infrastructure of PRISC (Portuguese Research Infrastructure of Scientific Collections). The IHC is funded by National funds through FCT —Fundação para a Ciência e a Tecnologia, I.P., under the projects UIDB/04209/2020 and UIDP/04209/2020. 